\title{
Mediating Effect of Perceived Organizational Support on the Relationship between Leader-Member Exchange and the Innovation Work Behavior of Nursing Employees: A Social Exchange Perspective
}

\author{
Qamar Zaman, Fahad Ahmed Qureshi, Mubeen Butt \\ Minhaj University Lahore \\ Minhaj University Lahore, Near Hamdard Chowk - Township, Lahore, Pakistan \\ Qamar.fc@hotmail.com
}

\begin{abstract}
The present study aimed at investigating the relationship between Leader-Member Exchange and Innovative Work Behavior in Pakistani nursing sector. Additionally, the study examined the relationship between Leader-Member Exchange as an independent variable and dependent variable Innovative Work Behavior moreover it has examined the impact of Leader-Member Exchange and Innovative Work Behavior further this explored mediating role of Perceived Organization Support between Leader-Member Exchange and Innovative Work Behavior. The main study was conducted through systematic randomly selected sample of 400 nurses of ages between 24 and 60 belonging to public and private sector hospitals at Lahore. Survey method was used to collect data. Correlation analysis exposed the significance and strength of relationships between variables i.e. Innovative Behaviour, Perceived Organizational Support (POS) and Leader-Member Exchange (LMX). Moreover, regression analysis was performed for direct relationships. Baron and Kenny (1986) method are used for mediation analysis. The results showed that Perceived Organizational Support (POS) partially mediate between Leader-Member Exchange (LMX) and Innovative Behaviour. The LMX and POS, POS and IWB and LMX and IWB have significant relation which are $0.569(0.000), 0.232(0.000)$ and $0.521(0.000)$.
\end{abstract}

Key Word- Perceived Organizational Support, Innovation Work Behavior, Leader-Member Exchange

\section{INTRODUCTION}

A worldwide marvel in today's human resource assumes a key part in accomplishing organizational results. Each worker undertakings to turn out to be an earth-shattering part of the competitive change and hierarchical achievement. Subsequently desired to change needs of the workplace, clients need through everyday communication, organizations need to give independence, freedom of work, supervisor coordination and organizational support building a trust-based relationship, access data and include in decision making process.

Research on perceived organizational support shows that as the organization stresses over the devotion of employees to them, same way employees are in like manner stressed with the commitment of organization to them. Employees ought to be quite regarded, as organization is the essential wellspring of their unmistakable advantages, for instance, health advantages and pay, and social advantages, for instance, profound respect and mind. A sign by the organization to be compensating for extending effort gives substance of obligation which adheres the workers to the organization. Higher perceived organizational support always develop more responsibility for any employees towards their organization (Hussain \& Asif, 2012).Leadership behaviour has straight and inimitable effect on the workplace, work results and the achievement of organizations (Ahmad \& Yekta, 2010). Past studies highlighted that workers' reaction to supervisor behaviour and organization's values shows a very strong impact on their enactment (Fu et al., 2006). Moreover, while Innovation Work Behavior is considered to incorporate a few measurements (problem identification, solution development, and solution support); (Stashevsky, Burke, Carmeli, Meitar, \& Weisberg, 2006). There is a developing group of writing about Innovation Work Behavior and its significance in the work environment. Nonetheless, there have been not very many studies that have satisfactorily analyzed the Innovation Work Behavior of nursing employees. To further extend very few studies have been conducted to analyze the organizational factors that are required to build up a situation that encourages the Innovation Work Behavior of nursing employees(Knol \& Van Linge, 2009). Accordingly, this examination will layout suggestions for hospital's administration and human resource managers trying to enhance organizational viability, efficiency, and patient results by building up the Innovation Work Behavior of nursing employees. The social organizations have a tendency to be 
commonly reliant and dependent upon the activities of someone else. Mutuality is not ordinarily utilized inside current literature; in any case, relationship of worker and supervisor has positively related.

\section{LITERATURE REVIEW}

Perceived Organizational Support (POS)

Researchers have argued that employees form global beliefs about how much an organization values their contributions and cares about their wellbeing (Eisenberger, Huntington, Hutchison, \& Sowa, 1986). These perceptions help employees determine whether their organizations recognize increased work effort, reward improved performance and enhance innovative behaviour (Lam, Liu, \& Loi, 2016). Nurses play a critical role in delivering exemplary health care. For nurses to perform at their best, they need to experience high engagement, which can be achieved by providing the necessary organizational support and proper working environment (Gupta, Agarwal, \& Khatri, 2016). According to (Jaiswal \& Dhar, 2016) the importance of good relations between superiors and subordinates, autonomy and freedom to employees in performing their jobs and support and guidance from superiors increasing commitment levels of employees which results in employees delivering high-quality service. Nurses' retention and motivation have become a major concern for hospitals and policymakers (Munir, Ghafoor, \& Rasli, 2016). A perceived organizational support system plays a significant role in generating a mutually comprehensive and healthy working environment, which ultimately plays a significant role in leading nursing sector. The supportive work environment which includes human resource practices also provides opportunities for participation and skills development which further enhance the motivation level of nursing staff. To enhance the affective commitment level among nursing staff, management and supervisors can implement various HRM practices related to Perceived organizational support (POS). In addition, countries with a collectivist culture such as Pakistan, employees anticipate support and care from their organization. In such a culture, supervisors can play a crucial role in strengthening the employee - organization relationship. In public sector, if nurses involve in the policy-making decision-making process the ultimate enhancing the performance (Sharma \& Dhar, 2016). POS acts as a critical mechanism through which supervisor support increases employees' engagement in the workplace (Jin \& McDonald, 2017). Nurses should not only engage in their work thoroughly, but also willing to perform beyond their normal job descriptions (Islam, Khan, Khawaja, \& Ahmad, 2017). (Trybou, Gemmel, Pauwels, Henninck, \& Clays, 2014) Past researchers have given more importance to the consequences of POS without discussing the process through which it influences the employee's workrelated outcomes. Moreover, Social Exchange Theory helps in understanding and to test the associations between other variables of current study that how POS predicts the mediator. Literature is well documented about emotional attachment, extra-role behaviour and work engagement as the reciprocation of POS (Shacklock, Brunetto, Teo, \& Farr-Wharton, 2014). The SET is of the view that to maximize the profits, both employees and employers should maintain a reciprocal relation (Blau, 1964) (Gouldner, 1960).

Leader Member Exchange (LMX)

Nurses having a good relationship with their supervisors are seen as important, yet the mechanisms of how such relationships are beneficial, or which aspects of the relationship are important, is less clear (Rodwell, McWilliams, \& Gulyas, 2017). LMX is based on the theoretical concepts and findings of role theory propounded by (Liden \& Maslyn, 1998) and focuses on the unique connection between leaders and their followers; a leader-member relationship is based on employment contract, interpersonal belief, esteem, dedication and communal responsibility (Srivastava \& Dhar, 2016). LMX explains the two-way relationship between a leader and followers, and has the following dimensions: contribution, affect, loyalty and selfdetermination (Liden \& Maslyn, 1998) (Graen \& UhlBien, 1995). Supervisors show more kindness and give positive evaluations of subordinate behaviour when both supervisors and subordinates share a high-quality working relationship. Therefore, employees who enjoy high-quality relationships with their leaders become obliged to reciprocate favourable treatment by showing their efforts on behalf of their supervisor or their organization (Garg \& Dhar, 2016). In an era of intense competition, organizations must understand and manage the intricacies of how leadership behaviour enhances or compromises the creation of a positive service climate (Auh, Bowen, Aysuna, \& Menguc, 2016). Work-family and leadership scholars are encouraged to build upon these findings through more complex research designs, including multi-level research and the incorporation of the supervisor-rated LMX (Litano, Major, Landers, Streets, \& Bass, 2016). A study conducted in French Hospitals in which shows that the differences in human resource management (HRM) practices between the non-profit health care 
sector and business life, the majority of health care sector research appears to be based on the HRM (for human resources management) blueprint for business life staff policy and practice for nurses. As nurses' dominant work orientation is based upon the fundamental concern for patients' welfare, it is important to carefully monitor the character of their job in order to guide the degree of organizational and professional support (Ruiller \& Van Der Heijden, 2016). Supportive leader behaviours such as in highquality LMX are most effective when they take place in the context of HRM systems that also signal social exchange (Audenaert, Vanderstraeten, \& Buyens, 2017). LMX considers advancement in the working interactions between leaders and direct subordinates. It comprises attributes of two-way respect, support and trust, which seek to promote access to information and contribution to decision making, the construct POS has a marginally stronger relationship with affective commitment compared with LMX (Robson \& Robson, 2016). The Social Exchange Theory (Blau, 1964) suggests that the actions of individuals depend on 'rewarding reactions' from others (Penger \& Černe, 2014). The focus is thus on reciprocity. Leadership can therefore be perceived as a social exchange between leaders and subordinates (Hsieh \& Wang, 2015);(Coxen, van der Vaart, \& Stander, 2016).

Innovative Work Behavior (IWB)

Despite a plethora of literature on organizational climate for innovation and the persuasive arguments establishing its link to perceived organizational support, few studies hitherto have explored innovative work behaviour of managers (Shanker, Bhanugopan, Van der Heijden, \& Farrell, 2017). Specifically, limited attention has been paid to explaining how organizations perceive the importance of stimulating innovative work environments. (Gupta et al., 2016) Nurses play a critical role in delivering exemplary health care. For nurses to perform at their best, they need to experience high engagement, which can be achieved by providing the necessary organizational support, innovative work behaviour and proper working environment. Employees' innovative work behaviour (IWB), defined as the development, adoption and implementation of new ideas for products, technologies and work methods by employees (Yuan \& Woodman, 2010), is often claimed to be an important determinant of organizational success. In the public sector, innovation is viewed as the factor that contributes to the quality of public services and the problem-solving capacity (De Vries, Bekkers, \& Tummers, 2016). The challenge to deliver ever more customized, reliable and technologically advanced patient care, quicker treatment response, efficient communication and coordination to increase patient retention and patient referral and increased quality of medical care has instigated hospital management to engender innovative work behaviours among their nursing staff. Self-evidently, the necessity for continuous innovation in hospitals is a crucial driving force for the greater benefit of the patients and the nursing community (Duarte, Goodson, \& Dougherty, 2014); (Piening, 2011).

Studying innovative employee behaviours within public sector organizations might seem an odd thing to do given the lack of competitive pressures, the limited identification of the costs and benefits of innovative ideas and the lack of opportunities to incentivize employees financially. In recent study (Bos-Nehles, Bondarouk, \& Nijenhuis, 2017), role of supervisors in supporting innovative work behavior (IWB) by considering the unique challenges, the conditions and characteristics of IWB in this context of nursing sector

After collection of the data, Statistical Program SPSS 17 will be used for inference and analysis.

The reliability will be operationalized through Cronbach Alpha analysis. The procedures recommended by Baron and Kenny (1986) will be used to investigate the mediating effects of POS on LMX and Innovative Behavior. Factor analysis will be carried out to check the dimensions of all operationally defined constructs and reliability and validity (convergent and discriminant) of the scales will be checked. All identified four steps will be conducted by running multiple regression analysis. Sobel test will be applied for the validation.

\section{METHODOLOGY}

The population of this research consists of chronicled nurses employing in the city Lahore. stratified random sampling technique was employed for data collection. Data was collected through questionnaires. A questionnaire is an effortless method of collecting data. They diminish deformation in data appropriate to 'interviewer biases' through the procedure of interview (Zikmund, 2003). Since the research intended to conclude the personal occurrences and beliefs might be sensitive in nature. This part consists of the following variables:

1. Innovative Work Behavior (Scott \& Bruce, 1994)

2. Leader-Member Exchange (LMX) (the quality of supervisor-subordinate relationship) (Graen \& Uhl-Bien, 1995) 


\section{HASIL DAN PEMBAHASAN}

Perceived Organizational Support (Eisenberger, Armeli, Rexwinkel, Lynch, \& Rhoades, 2001)

Table:1 Demographic Results

In the above table1, we have divided our respondents into different groups on the length of their service. We categorized our sample into four categorize of: less than 5 years, 5-10 years, $11-15$ years and $15+$ years. Here in the less than 5-year group comprises 126 respondents formulating $41.9 \%$ of total sample while 5-10 years' experience holding group comprises 84 respondents formulating 27.9\%, 11-15 Years' experience holding group comprises 68 respondents formulating $22.6 \%$ and at last $15+$ years experienced consist 23 respondents formulating $7.6 \%$ of the sample. Table:2 Descriptive Statistics

\begin{tabular}{|c|c|c|c|c|c|}
\hline \multirow{4}{*}{$\begin{array}{l}\text { Privat } \\
\text { e } \\
\text { Sector }\end{array}$} & Variable & $\begin{array}{c}\text { Mea } \\
\mathbf{n}\end{array}$ & $\begin{array}{c}\text { Std. } \\
\text { Deviati } \\
\text { on }\end{array}$ & $\begin{array}{c}\text { Skewne } \\
\text { ss }\end{array}$ & $\begin{array}{c}\text { Kurtos } \\
\text { is }\end{array}$ \\
\hline & $\begin{array}{l}\text { Innovative } \\
\text { Work } \\
\text { Behavior }\end{array}$ & $\begin{array}{c}2.61 \\
4\end{array}$ & .755 & .286 & .610 \\
\hline & $\begin{array}{l}\text { Leader } \\
\text { Member } \\
\text { Exchange } \\
(\text { LMX) }\end{array}$ & $\begin{array}{c}2.79 \\
8\end{array}$ & .763 & .290 & .090 \\
\hline & $\begin{array}{l}\text { Perceived } \\
\text { Organizatio } \\
\text { nal Support } \\
\text { (POS) }\end{array}$ & $\begin{array}{c}2.95 \\
8\end{array}$ & .717 & -.200 & .134 \\
\hline \multirow{3}{*}{$\begin{array}{c}\text { blic } \\
\text { Sector }\end{array}$} & $\begin{array}{l}\text { Innovative } \\
\text { Work } \\
\text { Behavior }\end{array}$ & $\begin{array}{c}2.57 \\
2\end{array}$ & .694 & -.138 & -.977 \\
\hline & $\begin{array}{l}\text { Leader } \\
\text { Member } \\
\text { Exchange } \\
\text { (LMX) }\end{array}$ & $\begin{array}{c}2.70 \\
2\end{array}$ & .830 & -.330 & -.330 \\
\hline & $\begin{array}{l}\text { Perceived } \\
\text { Organizatio } \\
\text { nal Support } \\
\text { (POS) } \\
\end{array}$ & $\begin{array}{c}2.61 \\
0\end{array}$ & .648 & -.303 & -.271 \\
\hline \multirow{2}{*}{$\begin{array}{c}\text { Overa } \\
\text { ll } \\
\text { Sampl } \\
\text { e }\end{array}$} & $\begin{array}{l}\text { Innovative } \\
\text { Work } \\
\text { Behavior }\end{array}$ & $\begin{array}{c}2.59 \\
9\end{array}$ & .733 & .162 & .179 \\
\hline & $\begin{array}{l}\text { Leader } \\
\text { Member } \\
\text { Exchange } \\
\text { (LMX) }\end{array}$ & $\begin{array}{c}2.76 \\
3\end{array}$ & .788 & .013 & -.021 \\
\hline
\end{tabular}

\begin{tabular}{lcccc}
\hline Perceived & & & & \\
Organizatio & 2.83 & .711 & -.155 & .019 \\
nal Support & 0 & & & \\
$($ POS $)$ & & & & \\
\hline
\end{tabular}

\section{DESCRIPTIVE STATISTICS:}

Here Table (2) represents the descriptive statistics of the dependent, mediator and independent variables. Respondents working in Private Sector revealed mean value of the dependent variable (Innovative Work Behavior) is 2.614 with standard deviation of 0.755 . In case of the independent variable (Leader Member Exchange) its mean value is 2.798 with standard deviation value of 0.763 while the Perceived Organizational Support (POS) has the mean value of 2.958 with standard deviation of 0.717 . Skewness and kurtosis result also depicted that all three variables are in normal range.

Mean values for nurses working at Public Sector hospitals revealed the mean value of the dependent variable (Innovative Work Behavior) is 2.257 with standard deviation of 0.694 . In case of the independent variable (Leader Member Exchange) its mean value is 2.702 with standard deviation value of 0.830 while the Perceived Organizational Support (POS) has the mean value of 2.61 with a standard deviation of 0.648 . Skewness and kurtosis result also depicted that all three variables are in normal range.

Table: 3 Reliability (Cronbach's Alpha) Statistics

\begin{tabular}{lcccc}
\hline & $\begin{array}{c}\text { Private } \\
\text { Sector }\end{array}$ & $\begin{array}{c}\text { Public } \\
\text { Sector }\end{array}$ & $\begin{array}{c}\text { Overall } \\
\text { Sample }\end{array}$ & $\begin{array}{c}\text { No. } \\
\text { of } \\
\text { Item } \\
\text { Sariable }\end{array}$ \\
\cline { 2 - 5 }
\end{tabular}

The purpose of Cronbach's alpha is to check the reliability of the variables in accordance with the related items included in the questionnaire, Cronbach's alpha utilized for the estimation of inner uniformity of the variables built from survey questions which discovers that how close these related survey questions are as a set to construct a variable. 
Table (3) discovered the Cronbach's alpha for the variables reliability values. The dependent variable Innovative Work Behavior has $\alpha$-value as 0.829 , the independent variable Leader-Member Exchange (LMX) has $\alpha$-value as 0.865 , and the mediator Perceived Organizational Support (POS) has $\alpha$-value as 0.830 . In the Private Sector, dependent variable Innovative Work Behavior has $\alpha$-value as 0.840 , the independent variable Leader-Member Exchange (LMX) has $\alpha$-value as 0.842 , and the mediator Perceived Organizational Support (POS) has $\alpha$-value as 0.821 .

In Public sector case, dependent variable Innovative Work Behavior has $\alpha$-value as 0.808 , the independent variable Leader-Member Exchange (LMX) has $\alpha$ value as 0.901, and the mediator Perceived Organizational Support (POS) has $\alpha$-value as 0.825 . The results of Cronbach's alpha support the phenomenon that the included items in the questionnaire are consistent and stable in this case.

Table:4 KMO \& Bartlett's Test of All Variables

\begin{tabular}{|c|c|c|}
\hline \multicolumn{2}{|c|}{$\begin{array}{l}\text { Kaiser-Meyer-Olkin (KMO) Measure of } \\
\text { Sampling Adequacy }\end{array}$} & 0.871 \\
\hline \multirow[t]{2}{*}{$\begin{array}{lll}\text { Bartlett's } & \text { Test } & \text { of } \\
\text { Sphericity } & & \end{array}$} & $\begin{array}{l}\text { Chi-Square } \\
\left(\chi^{2}\right) \\
\end{array}$ & 3041.443 \\
\hline & P-value & 0.0000 \\
\hline
\end{tabular}

Table 4: KMO \& Bartlett's Test of Each Variable

\begin{tabular}{l|lccc}
\hline \multicolumn{2}{l|}{} & $\begin{array}{l}\text { Innovative } \\
\text { Behavior }\end{array}$ & LMX & POS \\
\cline { 2 - 5 } $\begin{array}{l}\text { Kaiser-Meyer- } \\
\text { Olkin Measure of } \\
\text { Sampling } \\
\text { Adequacy. }\end{array}$ & 0.829 & 0.852 & 0.805 \\
\hline $\begin{array}{l}\text { Bartlett's } \\
\text { Test of } \\
\text { Sphericity }\end{array}$ & $\begin{array}{l}\text { Chi- } \\
\text { Square } \\
\left(\begin{array}{c}\left.\chi^{2}\right) \\
\text { Sig. }\end{array}\right.\end{array}$ & 631.441 & 890.362 & 904.321 \\
& 0.000 & 0.000 & 0.000 \\
\hline
\end{tabular}

\section{Convergent Validty}

It tends to examine that the constructs of the study that should be related are actually related or not. Of all the three dimensions of validity, the most widely used is Convergent validity; which is examined through Principal component analysis also known as Factor analysis with varix rotation method.

All the 21 items of the instrument were loaded into the factor analysis, and after the analysis no item was dropped as all the items were above the cut-off value of 0.50 for the factor loading used. Further we applied these KMO and Bartlett's test which also signifies the results and assumptions.

\section{LEADER-MEMBER EXCHANGE (LMX) AND INNOVATIVE WORK BEHAVIOR}

At first, we tested direct positive relationship between Leader-Member Exchange and Innovative Work Behavior. Table (8) revealed the linear regression results regarding the relationship between the LMX and Innovative Work Behavior in overall sample, Private and public sector cases.

\section{Table 5: Results of Leader-Member Exchange} (LMX) predicting Innovative Work Behavior

Although recent research from Scandinavia shows that public employees are not necessarily less innovative than employees in private organizations (Bysted \& Jespersen, 2014), in general we know little about the innovative behavior of employees in the public sector and even less how innovative behavior can be initiated, and supported (Bos-Nehles et al., 2017)

The results in Table (6) showed that LMX has a significant positive relationship with Perceived Organizational Support in all overall sample, private and public sector cases. In Overall sample case, the value of adjusted $\mathrm{R}^{2}$ of 0.395 showed that $\mathrm{LMX}$ explains $39.5 \%$ of variance in the Perceived Organizational Support, with $(F=196.795, p<.01)$. The Beta $(\beta)$ value of $0.569(p<.01)$ shows the extent to which Leader-Member Exchange affects Perceived Organizational Support of nursing staff. In Public Sector case, value of adjusted $\mathrm{R}^{2}$ of 0.493 showed that LMX explains $49.3 \%$ of variance in the Perceived Organizational Support, with $(F=106.904, p<.01)$. The Beta $(\beta)$ value of $0.705(p<.01)$ shows the extent to which Leader-Member Exchange affects Perceived Organizational Support of nursing staff in public sector. In Private sector case, value of adjusted $\mathrm{R}^{2}$ of 0.356 showed that LMX explains $35.6 \%$ of variance in the Perceived Organizational Support, with $(F=$ $106.904, p<.01)$. The Beta $(\beta)$ value of $0.599(p<.01)$ shows the extent to which Leader-Member Exchange affects Perceived Organizational Support of nursing staff in private sector.

PERCEIVED ORGANIZATIONAL SUPPORT AND INNOVATIVE BEHAVIOR

At first, we tested direct positive relationship between Perceived Organizational Support and Innovative Work Behavior. Table (07) revealed the linear regression results regarding the relationship between the POS and Innovative Work Behavior in overall sample, Private and Public sector cases.

Table 07: Results of Perceived Organizational Support and Innovative Behavior 
Note: linear regression result of Perceived Organizational Support (POS) predicting Innovative Work Behavior in overall sample, Private and Public sector cases.

The results in Table (07) showed that Perceived Organizational Support has a significant positive relationship with Innovative Work Behavior in all overall sample, private and public sector cases. In Overall sample case, value of adjusted $\mathrm{R}^{2}$ of 0.236

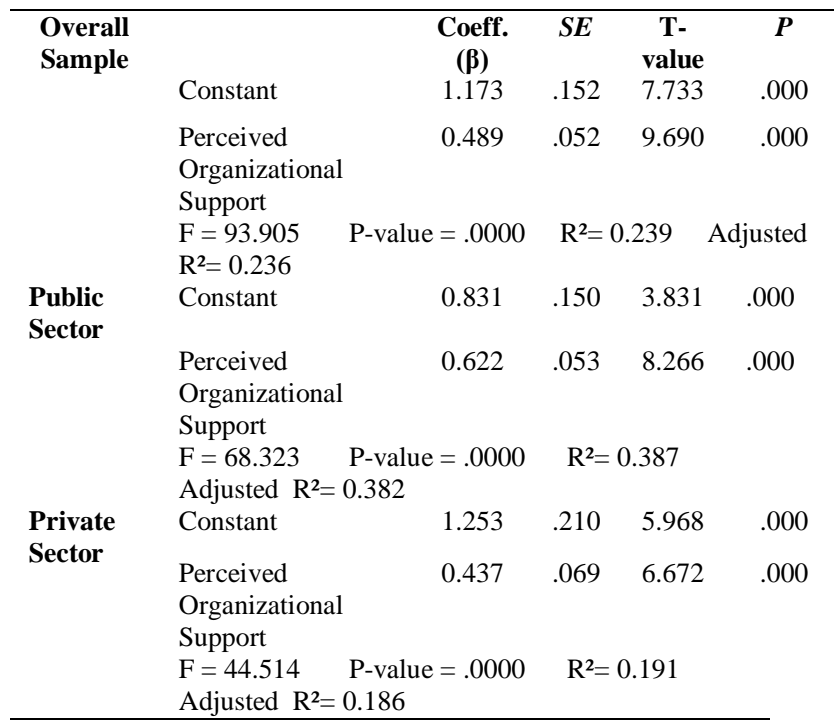

showed that LMX explains $23.6 \%$ of variance in the Perceived Organizational Support, with $(F=93.905$, $p<.01)$. The Beta $(\beta)$ value of $0.489(p<.01)$ shows the extent to which Perceived Organizational Support Affects Innovative Work Behavior of nursing staff. In Public Sector case, value of adjusted $\mathrm{R}^{2}$ of 0.382 showed that Perceived Organizational Support explains $38.2 \%$ of variance in the Innovative Behavior, with $(F=68.323, p<.01)$. The Beta $(\beta)$ value of 0.622 $(p<.01)$ shows the extent to which Perceived Organizational Support Affects Innovative Behavior of nursing staff in public sector. In Private sector case, value of adjusted $\mathrm{R}^{2}$ of 0.186 showed that Perceived Organizational Support explains $18.6 \%$ of variance in the Innovative Behavior, with $(F=44.514, p<.01)$. The Beta $(\beta)$ value of 0.437 ( $p<.01)$ shows the extent to which Perceived Organizational Support Affects Innovative Behavior of nursing staff in private sector.

\subsection{Hierarchical Regression for mediation Analysis} Table: 08 Mediation results

The results presented above in the Table-15, show that all paths were fully significant with p-value $<0.05$. This showed that Perceived Organizational Support (POS) partially mediated the relationship between Leader Member Exchange (LMX) and Innovative
Behavior. These above results showed that in Public Sector hospitals POS has stronger partially mediating effect (on the basis of their coefficient values) between the relationship LMX and Innovative work behavior with compare to Private Sector hospitals.

In order to further validate the findings of mediation test, Sobel's test (Sobel, Schmitt, \& Meriwether, 1990) has been utilized. The Table-16 shown below, presents the test statistic $(Z)$ which is well over 1.96 and p-value is also significant, which means that the results presented above were significant and Perceived Organizational Support (POS) mediated the relationship between Leader-Member exchange and Innovative Work Behavior.

Table: 09 Sobel Test Results

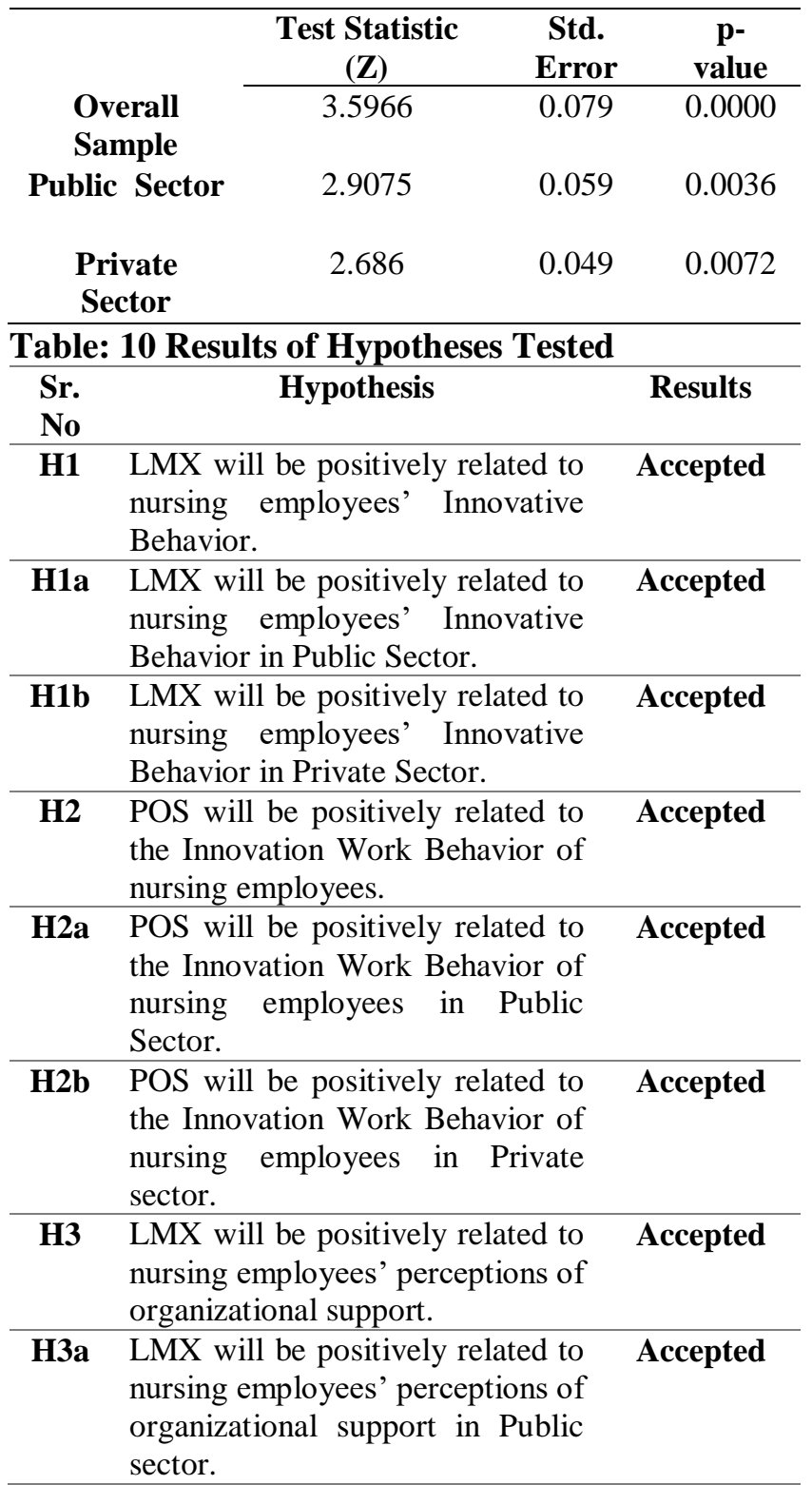




\begin{tabular}{|c|c|c|}
\hline H3b & $\begin{array}{l}\text { LMX will be positively related to } \\
\text { nursing employees' perceptions of } \\
\text { organizational support in Private } \\
\text { sector. }\end{array}$ & Accepted \\
\hline H4 & $\begin{array}{l}\text { POS mediates the relationship } \\
\text { between LMX and the Innovation } \\
\text { Work Behavior of nursing } \\
\text { employees. }\end{array}$ & $\begin{array}{l}\text { Partially } \\
\text { Mediated }\end{array}$ \\
\hline H4a & $\begin{array}{l}\text { POS mediates the relationship } \\
\text { between LMX and the Innovation } \\
\text { Work Behavior of nursing } \\
\text { employees. }\end{array}$ & $\begin{array}{l}\text { Partially } \\
\text { Mediated }\end{array}$ \\
\hline H4b & $\begin{array}{l}\text { POS mediates the relationship } \\
\text { between LMX and the Innovation } \\
\text { Work Behavior of nursing } \\
\text { employees. }\end{array}$ & $\begin{array}{l}\text { Partially } \\
\text { Mediated }\end{array}$ \\
\hline
\end{tabular}

\section{CONCLUSION}

This research has added a valuable contributed towards the literature of Social Exchange Theory. Moreover, nursing worker's effectiveness and capability are two modules are created for learning and convincing the better environment which can be created through Social Exchange Theory. In case that human resource managers and hospital supervisors can enhance nursing employees' behavior, competence, and effectiveness the comprehensive framework is made adding to the change of patient results and safety. Also, the study contributes knowledge to current writing giving confirmation that Innovative Work Behavior and current practices has reassure the perfect levels of support required by a relationship and also fill the gap between other supportive elements of IWB, POS and LMX.

Through this study, it has suggestions for medical organizations and heads, giving an understanding for the administration and it has to develop a strong relation and support Innovative Work Behavior in hospitals. The encroachment of Innovative Work Behavior is especially perilous for hospital management administration and managers, since it adds to enhancing worker conduct to expand hierarchical productivity and sustainability. Further supervisors and head nurses that effectively adjust worker behavior to organizational goal make a vigorous human resource function, that is, HR that precisely add to the fulfillment of organizational goal. Specifically, this study gives understanding into the significance of worker view of organizational backing and the employee-employer relationship. Besides, our outcomes suggested that workers see organizational support to be low; the suggestion for administration is to build up a strong methodology to enhance this observation in real scenario. Such a system ought to include, amongst different things, proper compensates which leads in a positive way and support for workers when they show Innovative Work Behavior.

With the support of significant literature and research work for future areas has highlighted for further exploration. Further instance that study has acknowledged to inside writing that work environment connections and the sharing of learning are variables that support and cultivate Innovative Work Behavior. In any case, there is an absence of empirical study looking at the effect of work environment connections which directly showed the Innovative Work Behavior of nurtures, in given paradigm further study has highlights the necessity under the banner of social exchange theory. This study showed a few glimpse of nurses and their supervisors relationship; thusly, more data is required from different departments of nurses, supervisors and head of nurses from all categories of hospitals either they are from public sector or from private sector to have the capacity to sum up and generalize from such discoveries in bigger scale. Therefore, this ought to provide more information regarding the relationship of nurses and the organizations.

As we earlier mentioned, this study has a cross-section of the relationship between innovative work behavior, leader member exchange and perceived organizational support and that cross study sectional study characterizes limitations to research. On the grounds that such information is not fitting for concluding generalizable causal implications. Thusly, advance exploration giving a longitudinal method ought to give further understanding into the Innovative Work Behavior of nursing workers. Through this study which showed that leader member exchange is positively influenced perceived organizational support, however in private sector perceived organizational support was still observed to be low. In this way, encourage research looking at different precursors of POS may give a superior general understanding of the components that straight forwardly and in an oblique way impact of Innovative Work Behavior in public and private sector. At the end, results showed that in Public Sector hospitals POS has stronger partially mediating effect (on the basis of their coefficient values) between the relationship LMX and Innovative work behavior with compare to Private Sector hospitals. 


\section{REFERENSI}

[1] Abu Bakar, H., Su Mustaffa, C., \& Mohamad, B. (2009). LMX quality, supervisory communication and team-oriented commitment: A multilevel analysis approach. Corporate Communications: An International Journal, 14(1), 11-33.

[2] Ahmad, Z. A., \& Yekta, Z. A. (2010). Relationship between perceived organizational support, leadership behavior, and job satisfaction: An empirical study in Iran. Intangible Capital, 6(2), 162-184.

[3] Anderson, J. C., \& Gerbing, D. W. (1988). Structural equation modeling in practice: A review and recommended two-step approach. Psychological bulletin, 103(3), 411.

[4] Audenaert, M., Vanderstraeten, A., \& Buyens, D. (2017). When affective well-being is empowered: The joint role of leader-member exchange and the employment relationship. The International Journal of Human Resource Management, 28(15), 2208-2227.

[5] Auh, S., Bowen, D. E., Aysuna, C., \& Menguc, B. (2016). A search for missing links: specifying the relationship between leader-member exchange differentiation and service climate. Journal of Service Research, 19(3), 260-275.

[6] Bhal, K. T., \& Ansari, M. A. (2007). Leadermember exchange-subordinate outcomes relationship: Role of voice and justice. Leadership \& Organization Development Journal, 28(1), 20-35.

[7] Blau, H. (1964). The Impossible Theater: A Manifesto: Macmillan.

[8] Bos-Nehles, A., Bondarouk, T., \& Nijenhuis, K. (2017). Innovative work behaviour in knowledge-intensive public sector organizations: the case of supervisors in the Netherlands fire services. The International Journal of Human Resource Management, 28(2), 379-398.

[9] Brunetto, Y., Farr-Wharton, R., \& Shacklock, K. (2011). Supervisor-nurse relationships, teamwork, role ambiguity and well-being: Public versus private sector nurses. Asia Pacific Journal of Human Resources, 49(2), 143-164.

[10] Brunetto, Y., Farr-Wharton, R., \& Shacklock, K. (2010). The impact of supervisor-subordinate relationships on morale: implications for public and private sector nurses' commitment. Human Resource Management Journal, 20(2), 206-225.
[11] Bysted, R., \& Jespersen, K. R. (2014). Exploring managerial mechanisms that influence innovative work behaviour: Comparing private and public employees. Public Management Review, 16(2), 217-241.

[12] Coxen, L., van der Vaart, L., \& Stander, M. W. (2016). Authentic leadership and organisational citizenship behaviour in the public health care sector: The role of workplace trust. SA Journal of Industrial Psychology, 42(1), 1-13.

[13] De Vries, H., Bekkers, V., \& Tummers, L. (2016). Innovation in the public sector: A systematic review and future research agenda. Public administration, 94(1), 146-166.

[14] Denzin, N. K. (1973). The research act: A theoretical introduction to sociological methods: Transaction publishers.

[15] Duarte, N. T., Goodson, J. R., \& Dougherty, T.M. P. (2014). Managing innovation in hospitals and health systems: Lessons from the Malcolm Baldrige National Quality Award Winners. International Journal of Healthcare Management, 7(1), 21-34.

[16] Eisenberger, R., Armeli, S., Rexwinkel, B., Lynch, P. D., \& Rhoades, L. (2001). Reciprocation of perceived organizational support. Journal of Applied Psychology, 86(1), 42.

[17] Eisenberger, R., Huntington, R., Hutchison, S., \& Sowa, D. (1986). Perceived organizational support. Journal of Applied psychology, 71(3), 500.

[18] Ellemers, N., Kingma, L., van de Burgt, J., \& Barreto, M. (2011). Corporate social responsibility as a source of organizational morality, employee commitment and satisfaction. Journal of Organizational Moral Psychology, 1(2), 97-124.

[19] Fu, P., Tsui, A., Liu, J., Song, J., Jiang, Y., Jia, L., ... Wu, W. (2006). CEO personal values and middle manager responses: The mediating role of leadership behavior and organizational culture. Research Grants Council of the Hong Kong special Administrative Region, China.

[20] Garg, S., \& Dhar, R. L. (2016). Extra-role customer service: The roles of leader-member exchange (LMX), affective commitment, and psychological empowerment. International Journal of Hospitality \& Tourism Administration, 17(4), 373-396.

[21] Gerbing, D. W., \& Anderson, J. C. (1988). An updated paradigm for scale development 
incorporating unidimensionality and its assessment. Journal of marketing research, 186192.

[22] Gouldner, H. P. (1960). Dimensions of organizational commitment. Administrative Science Quarterly, 468-490.

[23] Graen, G. B., \& Uhl-Bien, M. (1995). Relationship-based approach to leadership: Development of leader-member exchange (LMX) theory of leadership over 25 years: Applying a multi-level multi-domain perspective. The leadership quarterly, 6(2), 219-247.

[24] Gupta, V., Agarwal, U. A., \& Khatri, N. (2016). The relationships between perceived organizational support, affective commitment, psychological contract breach, organizational citizenship behaviour and work engagement. Journal of advanced nursing, 72(11), 28062817.

[25] Hsieh, C.-C., \& Wang, D.-S. (2015). Does supervisor-perceived authentic leadership influence employee work engagement through employee-perceived authentic leadership and employee trust? The International Journal of Human Resource Management, 26(18), 23292348.

[26] Hussain, T., \& Asif, S. (2012). Is employees' turnover intention driven by organizational commitment and perceived organizational support. Journal of quality and technology management, 8(2), 1-10.

[27] Islam, T., Khan, M. M., Khawaja, F. N., \& Ahmad, Z. (2017). Nurses' reciprocation of perceived organizational support: the moderating role of psychological contract breach. International Journal of Human Rights in Healthcare, 10(2), 123-131.

[28] Jaiswal, D., \& Dhar, R. L. (2016). Impact of perceived organizational support, psychological empowerment and leader member exchange on commitment and its subsequent impact on service quality. International Journal of Productivity and Performance Management, 65(1), 58-79.

[29] Jin, M. H., \& McDonald, B. (2017). Understanding employee engagement in the public sector: The role of immediate supervisor, perceived organizational support, and learning opportunities. The American Review of Public Administration, 47(8), 881-897.
[30] Knol, J., \& Van Linge, R. (2009). Innovative behaviour: the effect of structural and psychological empowerment on nurses. Journal of Advanced Nursing, 65(2), 359-370.

[31] Lam, L. W., Liu, Y., \& Loi, R. (2016). Looking intra-organizationally for identity cues: Whether perceived organizational support shapes employees' organizational identification. Human Relations, 69(2), 345-367.

[32] Liden, R. C., \& Maslyn, J. M. (1998). Multidimensionafity of leader-member exchange: An empirical assessment through scale development. Journal of management, 24(1), 43-72.

[33] Litano, M. L., Major, D. A., Landers, R. N., Streets, V. N., \& Bass, B. I. (2016). A metaanalytic investigation of the relationship between leader-member exchange and workfamily experiences. The leadership quarterly, 27(5), 802-817.

[34] Masood, M., \& Afsar, B. (2017). Transformational leadership and innovative work behavior among nursing staff. Nursing inquiry, 24(4), e12188.

[35] Munir, Y., Ghafoor, M. M., \& Rasli, A. M. (2016). Exploring the relationship of horizontal violence, organizational cynicism and turnover intention in the context of social exchange theory. International Journal of Human Rights in Healthcare, 9(4), 254-266.

[36] Patton, M. Q. (1999). Enhancing the quality and credibility of qualitative analysis. Health services research, 34(5 Pt 2), 1189.

[37] Penger, S., \& Černe, M. (2014). Authentic leadership, employees' job satisfaction, and work engagement: A hierarchical linear modelling approach. Economic researchEkonomska istraživanja, 27(1), 508-526.

[38] Piening, E. P. (2011). Insights into the process dynamics of innovation implementation: the case of public hospitals in Germany. Public Management Review, 13(1), 127-157.

[39] Reid, M. F., Allen, M. W., Riemenschneider, C. K., \& Armstrong, D. J. (2006). Affective commitment in the public sector: the case of IT employees. Paper presented at the Proceedings of the 2006 ACM SIGMIS CPR conference on computer personnel research: Forty four years of computer personnel research: achievements, challenges \& the future.

[40] Robson, A., \& Robson, F. (2016). Investigation of nurses' intention to leave: a study of a sample 
of UK nurses. Journal of health organization and management, 30(1), 154-173.

[41] Rodwell, J., McWilliams, J., \& Gulyas, A. (2017). The impact of characteristics of nurses' relationships with their supervisor, engagement and trust, on performance behaviours and intent to quit. Journal of advanced nursing, 73(1), 190200.

[42] Rubin, A., \& Babbie, E. (2005). Research methods for social work . Belmont: Thomson Learning: Inc.

[43] Ruiller, C., \& Van Der Heijden, B. I. (2016). Socio-emotional support in French hospitals: Effects on French nurses' and nurse aides' affective commitment. Applied nursing research, 29, 229-236.

[44] Scott, S. G., \& Bruce, R. A. (1994). Determinants of innovative behavior: A path model of individual innovation in the workplace. Academy of management journal, 37(3), 580-607.

[45] Shacklock, K., \& Brunetto, Y. (2012). The intention to continue nursing: work variables affecting three nurse generations in Australia. Journal of advanced nursing, 68(1), 36-46.

[46] Shacklock, K., Brunetto, Y., Teo, S., \& FarrWharton, R. (2014). The role of support antecedents in nurses' intentions to quit: the case of Australia. Journal of advanced nursing, 70(4), 811-822.

[47] Shanker, R., Bhanugopan, R., Van der Heijden, B. I., \& Farrell, M. (2017). Organizational climate for innovation and organizational performance: The mediating effect of innovative work behavior. Journal of Vocational Behavior, 100, 67-77.

[48] Sharma, J., \& Dhar, R. L. (2016). Factors influencing job performance of nursing staff: mediating role of affective commitment. Personnel Review, 45(1), 161-182.
[49] Sobel, J. D., Schmitt, C., \& Meriwether, C. (1990). A new slide latex agglutination test for the diagnosis of acute Candida vaginitis. American journal of clinical pathology, 94(3), 323-325.

[50] Srivastava, A. P., \& Dhar, R. L. (2016). Impact of Leader member exchange, human resource management practices and psychological empowerment on extra role performances: the mediating role of organisational commitment. International Journal of Productivity and Performance Management, 65(3), 351-377.

[51] Stashevsky, S., Burke, R., Carmeli, A., Meitar, R., \& Weisberg, J. (2006). Self-leadership skills and innovative behavior at work. International Journal of Manpower, 27(1), 75-90.

[52] Trybou, J., Gemmel, P., Pauwels, Y., Henninck, C., \& Clays, E. (2014). The impact of organizational support and leader-member exchange on the work-related behaviour of nursing professionals: The moderating effect of professional and organizational identification. Journal of advanced nursing, 70(2), 373-382.

[53] Wang, X. H., Fang, Y., Qureshi, I., \& Janssen, O. (2015). Understanding employee innovative behavior: Integrating the social network and leader-member exchange perspectives. Journal of Organizational Behavior, 36(3), 403-420.

[54] Yuan, F., \& Woodman, R. W. (2010). Innovative behavior in the workplace: The role of performance and image outcome expectations. Academy of Management Journal, 53(2), 323-342. 